\title{
Discourse Analysis: Ronald Reagan's Evil Empire Speech
}

\author{
Juliana Vianna da Nobrega \\ Otto von Guericke University Magdeburg, Magdeburg, Germany \\ Email: julianavnn@yahoo.com.br
}

Received 7 November 2013; revised 10 December 2013; accepted 17 December 2013

Copyright (C) 2014 by author and Scientific Research Publishing Inc.

This work is licensed under the Creative Commons Attribution International License (CC BY). http://creativecommons.org/licenses/by/4.0/

(c) (i) Open Access

\begin{abstract}
Language can be a powerful tool to convince others and make them cooperative. Cialdini (2007) has worked out several principles along which it is possible to analyze discourses in terms of their persuasiveness. Others also have contributed with tools to analyzing discourses such as Fairclough (2003). These tools are used to analyze the "Evil Empire Speech" of the US President Ronald Reagan that he held at the National Association of Evangelicals, 1983, in Orlando Florida. His historical speech was aimed at convincing the nation about the righteousness of his nuclear policy. He partly rewrote the already prepared script and included the "evil empire" part. The analysis supports that his speech was an exceptionally effective one. Reagan made his speech an example of the following principles of persuasiveness such as reciprocity, authority, commitment, liking, scarcity and social proof. He wanted support for belligerent intentions from a faithful community, which was already problematic, but he got the audience on his side through emphasizing his similarities with them, his own faithfulness, the presentation of strong examples and balancing humor and seriousness. Additionally, he introduced the striking metaphor "evil empire", which stuck to the peoples' minds and had an impact on them. He also appealed to the people through implicitly distinguishing the evil from the ones who were not evil-the US citizens. Thus, he made the American people feel better, to ensure them that they do the right thing when following him. He ranked religious people above him when he was joking about clergy men and politicians. To reinforce his authority, he borrowed the authority of various respected men through citing them. He improved his position and the power of his arguments using the philosophical wisdom of others.
\end{abstract}

\section{Keywords}

Discourse Analysis; Ronald Reagan; Speech; Persuasion

\section{How to Make the Best Out of a Speech?}

Life normally consists to an enormous amount of communication, so does my life as well. My own experience 
with group works at the University of Magdeburg showed that communication can be very difficult and time consuming but also easy, effective and efficient. I do have the same experience with presentations or lectures. Independent of whether I found the matter interesting upfront, some people turn the presentation into something that catches my attention or they make me fight with drifting away and thinking of something else. Often enough I am in the position to give speeches myself and I am sure that people think the same way of what I present them-either one or the other way.

From my point of view, some persons have the quality of nearly always doing a good job during speeches and sometimes they do it even exceptionally well. For me, one of those persons was Ronald Reagan, the president of the United States from 1981-1989.

Anyway, I find it quite challenging to find out what about his speeches make them so attractive to me and certainly to other people as well. But to know that would probably prevent me from spending much of my energy on unfruitful attempts to convince somebody of my findings. Therefore, I will dedicate myself to finding a way to properly learn more about Reagan's qualities and weaknesses in communication.

To do so I have to find out what the communication style of Reagan was and what the features of his style were that made him persuasive. This should be a well structured analysis regarding all the dimensions of communication and persuasiveness because only this focused view makes the difference from just passively listening to what he says.

The speech of Ronald Reagan will be analyzed, and the context of his speech will be outlined before the actual analysis. Upfront, I will explain the tools and at the same time theoretical background that I will use to analyze his speech. A basic part of these tools are the principles of persuasion from Robert Cialdini: reciprocation, commitment and consistency, social proof, authority, liking and scarcity (Cialdini, 2007: $1 \mathrm{ff}$.). Not each of those might be relevant, but for those which are, reasons will be given. Additionally, the Critical Discourse Analysis will be used as a means of analysis. This method will also be explained initially.

\section{Language and the Principles of Persuasion}

In a new functional approach, language is designed as a form of action and as a place of interaction. One can observe the effect that these expressions have in social interaction because the linguistic manifestations, which a certain speaker produces (in a real situation of communication under determined conditions of interaction), demonstrate the discursive intention of the speaker. In the linguistic system the speaker reveals his communicative propositions.

The functional use of language occurs when a language is used considering different interlocutive propositions and being adapted to various discursive contexts (Neves, 1997: 15). The speaker chooses a vocabulary with words that are adapted to his communicative intentions. This choice is not realized through a particular word but through the organization and combination of various words. Each choice, which the speaker makes, has a discursive function. The speaker chooses the words in accordance with what he wants to communicate.

The discourse is an activity that is marked by the oral ability whereas the voice and the gestures are elements, which establish a discrete and sensorial communication, and with their theatricality express and articulate meanings of the inner universe, giving everything a draping of intention to the word. The form of discourse is as important as the content. The way how a discourse is held is how it gives power and substance to the word (Vieira, 1993: 61).

The discourses are also conditioned to the context in which they are produced. The social context is the environment in which the text is produced, and the cultural context is the background where the interaction is happening. The choices obtain significance in a socio-cultural context. Because of that, it is not correct to say that an expression is right or wrong, but that this expression is (or is not) adequate in the context. Discourses are always socially situated since they take place in social environments. Furthermore, the discourse is systemically and predictably constructed that way that it relates to these contextual circumstances (Richardson, 2007: 75).

In this sense, in the process of persuasion there is a utilization of elements and techniques (by the speaker) trying to mobilize emotions in the listener, which help the speaker to reach agreement (among the listeners) and in the following change his or her behavior. There exists a specific methodology of persuasion. An art that analyzes and defines the steps through which a person tries to convince other people and that identifies its structural fundaments.

Robert Cialdini developed a theory based on the principles of persuasion, which are: 
Reciprocation is about repaying what one has received from another one. People seem to be tempted to give something back when they have received a favor in advance. Furthermore, asking for very big favors would mostly immediately be rejected, but asking in the following for a smaller one raises much more the likelihood that the smaller one would be accepted.

The rule says that people should try to repay what another person has provided them. If a man does us a favor, we should do him one in return. We are obligated to the future repayment of favors, it has become a synonym for "thank you" (Cialdini, 2007: 18).

Sociologists (such as Alvin Gouldner) affirm that there is no human society that does not subscribe to the rule. It may well be that a developed system of indebtedness flowing from the rule for reciprocation is a unique property of human culture. An enormous shared and strongly held feeling of future obligation made a big difference in human social evolution, because it meant that one person could give, for example food, to another with confidence that it was not being lost. Such a system of aid (reciprocation) became possible bringing benefit to the societies that possessed it. This rule is deeply implanted in us by the process of socialization (Cialdini, 2007: 18).

A good example to illustrate this is the case of five thousand dollars of relief aid sent to Mexico from people of Ethiopia. In 1985 native officials of the Ethiopian Red Cross had decided to send the money to help the victims of that year`s earthquakes in Mexico city. A journalist asked them for an explanation about the donation and the officials answered that despite the needs prevailing in their country, the money was sent because Mexico had sent aid to Ethiopia in 1935, when it was invaded by Italy (Cialdini, 2007: 19).

Human societies are trained to comply with and believe in the reciprocity rule, and each of us knows about the social sanctions and derision applied to anyone who violates it. There is a general distaste for those who take and make no effort to give in return. In this sense, on the example illustrated it is possible to observe that the need of reciprocation had triumphed even a half century later (Cialdini, 2007: 20).

Commitment and consistency: To be consistent is another human motivation. If one can get commitment from a person in the form of a verbal or written agreement, it is much more likely that the person will do it. Cialdini calls it getting the answer 'yes'.

This principle shows that once a man has made a choice, he will encounter personal and interpersonal pressures to behave consistently with that commitment. There is a desire to be and to appear consistent with what he has already done. Those pressures will cause him to respond in ways that justify his earlier decision.

Even in ways that are clearly contrary to the human beings' own best interests the tendency to be consistent is strong enough to compel people to do what they ordinarily would not want to do. In New York City beach there was an experiment made for the psychologist Thomas Moriarty which proofed that. In the experiment, a research accomplice would put a beach blanket down five feet from the blanket of another person, who was chosen as the experimental subject. After some minutes the accomplice would stand up and leave the blanket to stroll down the beach. A few minutes later, a second researcher, pretending to be a thief, would come, grab the radio and try to hurry away with it. The persons were very reluctant to put themselves in harm `s way by challenging the thief. But when the procedure was tried with the accomplice, before taking his stroll, asking the experimental subject "watch my things", which they agreed to do, the result was different. Now, the subjects (nineteen of the twenty subjects) became virtual vigilantes and running after and stopping the thief, demanding an explanation. They were propelled by the rule for consistency (Cialdini, 2007: 59).

Social proof: People, who are not sure what to do, look for orientation in the people around them. Others do it, so they do it as well.

Persons view a behavior as more correct in a given situation to the degree that they see others performing it. The tendency to see an action as more appropriate when others are doing it normally works well. When a lot of people are doing something, it is the right thing to do. For example, advertisers like to inform the consumers when a product is the "largest-selling" because they do not have to convince them directly that the product is good, they need only say that many others think so and then, it seems proof enough (Cialdini, 2007: 117).

This tendency, to assume that an action is more correct when others are doing it, is exploited in a variety of settings. The psychologist Albert Andura has shown how people suffering from phobias can get rid of these fears in a simple fashion. He made a study of children who were exceptionally afraid of dogs. These children should watch a little boy playing happily with a dog for twenty minutes a day. After four days of exhibition it produced changes in the reactions of the fearful children and 67 percent of them were willing to climb into a playpen with a dog for playing and petting. The children were more willing to interact with a dog after the exhi- 
bition (Cialdini, 2007: 118).

Authority: People look up to authority. They find it in the form of experts, titles, clothing and status. Those factors improve credibility even though it might not always be legitimate.

Persons are trained from birth onwards that obedience to proper authority is right and disobedience is wrong. The power and value of obedience is in our culture. During the childhood children found that taking their parents advice proved beneficial because their parents have wisdom and also because they controlled punishments. As adults the pattern persists, but now other authority figures appear as judges, employers and government leaders. Their positions go together with superior access to information and power. It makes sense to comply with the wishes of these authorities even when it makes no sense at all. The obedience frequently takes place with little or no conscious deliberation. People rarely think about the pros and cons of authority's demands (Cialdini, 2007: 218).

In this sense, a good example could be the authority of physicians. Their authority is often not questioned. The various health workers well understand the level of their jobs in this structure and they see that the M.D. sits at the top. Just another doctor of higher rank would, perhaps, overrule the doctor's judgment in a case, no one else. As a consequence there is a tradition of automatic obedience to a doctor's orders among health-care staff. Professor Cohen affirms that when a physician makes a clear error no one lower in the hierarchy questions the prescription (Cialdini, 2007: 219).

Liking: People will agree more to people they like. The reasons for people to like other people can be very diverse. It might be attractiveness, similarity, etc.

There are factors that can be used to produce linking. The first one is physical attractiveness. Good-looking people have an advantage in social interaction. There are evidences of favoritism toward handsome politicians. Research demonstrated that voters do not realize their bias (Cialdini, 2007: 171). The second is similarity, people like others that are similar to them in the area of opinions, personality traits, background or life-style. The similarities may seem trivial, but they appear to work (Cialdini, 2007: 173). The third is compliment. The information that someone fancies a person can be a device for producing return linking and willing compliance. The actor McLean Stevenson described how his wife tricked him into marriage: "She said she liked me." Persons hear a positive estimation from others who want something back (Cialdini, 2007: 174). Fourth, contact and cooperation. People like things that are familiar to them. Because of its effect on liking, familiarity plays a role in decisions as, for example, the politicians people elect. In the Ohio election, a man given little chance of winning the state attorney-general race reached the victory before the election, through changing his name to a family name with political tradition in Ohio (Brown). People often do not realize that their attitude toward something has been influenced by the number of times they have been exposed to that in the past. Cooperation is a powerful cause of liking too. When people are working for the same goals, for mutual benefits, they are teammates. In an experiment researchers could observe that rival boys in a holiday camp after working together for common goals through "cooperative learning" achieved these goals. Because the success resulted from the mutual efforts (cooperation), it became difficult to maintain feelings of hostility toward those who had been teammates in the triumph (Cialdini, 2007: 181). Finally, liking through conditioning and association is presented. The simple association with something is enough to stimulate people to like or dislike something. Negative association can be exemplified in the case of a TV weatherman, who often gave bad news about the weather. The watchers did not like him and one guy even threatened to shoot him if he did not stop the rain. The positive association can be proofed through the liking of celebrities to products, for example, professional athletes are paid to connect themselves to some products even when it is irrelevant to their roles. The important thing for the advertiser is to establish a positive connection (Cialdini, 2007: 188).

Scarcity: Since people want and value scarce things more than things that are around in abundance, they would be more attentive when there is an opportunity to get such a scarce thing.

This principle has notable power in directing human action. When people note that their freedom to have something is limited, the item becomes less available and they experience an increased desire for it. Nevertheless, people do not recognize that psychological reactance has caused them to want the item more, they just know that they want it.

The idea of potential loss plays a role in human decision making. It was proofed that pamphlets using young women to check for breast cancer are more successful if they state their case in terms of what stands to be lost, for example: "You can lose several potential health benefits by failing to spend only five minutes each month doing breast self-examination.” (Cialdini, 2007: 239). Something that had little appeal for the young women 
(breast test through self-examination) had become more attractive merely because they could lose many potential health benefits in not doing it. The scarcity principle says that opportunities seem more valuable to people when their availability is limited.

I will ratify Cialdini's theory of persuasion with Reagan's Evil Empire speech. For this reason, I will support my analysis with the method of Critical Discourse Analysis (CDA) and with Norman Fairclough in "Analyzing discourse".

\section{Critical Discourse Analysis}

\subsection{Critical Discourse Analysis as a Method in Social Scientific Research}

For Fairclough Critical Discourse Analysis (CDA) is as much theory as method (Wodak/Meyer, 2001: 121). In this study, it will be referred to CDA as a method of discourse analysis. CDA is seen as a resource for critical social research that is used in combination with theoretical and analytical resources in various areas of social science.

Fairclough explains that discourse can be an element of social practice. This means that the discourse has a specific genre, which makes reference to the way of acting. The discourse is a way of representing and a style which refers to the way of being (Fairclough, 2003: 26). In the specific case treated in this paper, the genre is a public discourse, held from the former president of the United States, Ronald Reagan, at the National Association of Evangelicals in Orlando, Florida, where various reporters were present.

Fairclough (2003: 40) points out that there are three themes in social research, which should be studied. The first one is social difference. The particular social identities give way to political struggles based on the interests and identities of such particular groups. People differ in all sorts of ways and orientation. Difference is fundamental to social interaction. Reagan's discourse was based around the interests and identities of evangelical people. The second theme is the universal and the particular. The issue here is how particular identities, interests and representations can-under certain conditions-be claimed to be universal. This issue can be framed within questions of hegemony, for example, politics is seen as a struggle for hegemony, a particular way of conceptualizing power emphasizes how power depends upon achieving consent and the importance of ideology in sustaining relations of power (Fairclough, 2003: 45). The third theme is ideology. Habermas affirmed that "language is also a medium of domination and social force. It serves to legitimize organized power. In so far as the legitimations of power relations [...] are not articulated [...] language is also ideological” (Wodak/Meyer, 2001: 2).

Therefore, the analysis of a discourse is a preoccupation across the social sciences. Discourses are ways of representing aspects of the world. Different discourses are different points of view on the world. In the case of Reagan's speech, the new perspective on the world is a nuclear policy. This discourse is an element of social practice and will be analyzed through the Method of Critical Discourse Analysis (CDA).

\subsection{The Method of Critical Discourse Analysis (CDA)}

The Critical Discourse Analysis (CDA) takes into account the context of language use and, additionally, the relation between language and power. CDA theorizes social processes (within which individuals or groups create meanings in their interaction with texts) and structures which give rise to the production of a text. In this sense, three concepts are present in discourse analysis: power, history and ideology. This method of analysis considers that every discourse is historically produced and interpreted; discourses are structured by dominance and dominance structures are dominated by ideologies of powerful groups. Using CDA as a method of discourse analysis makes it possible to understand the effects of power and ideology in the production of meaning (Wodak/Meyer, 2001: 3). Thus, this method of analysis has been chosen in the present study.

Van Dijk affirms that CDA shall analyze the socio-cognitive aspect of the discourse analysis. The study of cognition is important for him while doing a critical analysis of discourse, communication and interaction (Wodak/Meyer, 2001: 97).

Cognition is understood as "personal and social cognition, beliefs and goals as well as evaluations and emotions, and any other "mental" or "memory" structures representations or processes involved in discourse interaction” (Wodak/Meyer, 2001: 98). Discourse analysis requires detailed cognitive and social analysis.

Methods of research depend on the characteristics of the context of the scholarly investigation such as aims, 
participants, setting, users and their beliefs and interests.

We must make choices selecting those structures that are necessary while analyzing discourses. Thus, when I analyze the way that Reagan exercised power and influence through his discourse, it only makes sense to study those properties that can vary as a function of social power as, for example, stress and intonation, word order, lexical style, coherence, topic choices, speech acts, schematic organization and rhetorical figures.

I shall explain some of the most important structures used in my analysis. Table 1 summarizes the following items that I will use in the discourse analysis. The first one is the use of the topic. The topic plays an important role in the processes of communication and interaction. The topic represents what a discourse 'is about'. Topics define what speakers orient towards and also allow for influence and manipulation. Second, there are the local meanings. They are the result of the selection made by speakers in their mental models of events. The local meanings are the kind of information that influences the mental models and therefore the attitudes and opinions of recipients. When using CDA as a method of discourse analysis, I shall observe the study of ideologically biased discourses. Moreover, it is interesting to study the use of implicit meanings because this kind of meanings is related to underlying beliefs.

Additionally, the CDA is interested in studying the structures that are less controllable by the speakers for example: intonation, rhetorical figures and all forms of spontaneous talk (i.e. pauses). These structures do not show directly underlying meanings and hence the identity of the speakers may be signaled by subtle characteristics of talk. Speakers may emphasize good things by ordering positive meanings in topics, by providing many details about good things, few details about bad things, using positive metaphors and by leaving implicit negative properties aside. In a (dominance) discourse the way of speaking not only expresses power, but also the desire to influence, to manipulate and to control the minds of the recipients.

Regarding context of the discourse, we may argue that the location of the discourse influences the speech. The characteristics of a speech change concerning the domain where it happens and according to the purposes, for example, politics or business, legislation or propaganda. Van Dijk affirms: "That is, what we say and how we say it depends on who is speaking to whom, when and where, and with what purposes” (Wodak/Meyer, 2001: 108). Context models guide us to understand what is relevant to the social situation for the speech participants. It links texts with social situations.

Event models are another point that should be observed. Van Dijk notes: "Language users not only form mental models of the situation they interact in, but also of the events or situations they speak or write about" (Wodak/Meyer, 2001: 111). The discourses are understood as coherent in relation to the mental models that the users have about the events (facts) referred to.

Van Dijk classifies three forms of social representations that are necessary to understand a discourse: 1) knowledge (personal, group, cultural); 2) attitudes (attitudes are socially shared opinions); 3 ) ideologies. Table 2 summarizes these findings. Discourses occur within society and therefore can only be understood in the interaction of social situation, action, actor and societal structures (Wodak/Meyer, 2001: 21).

Table 1. Items used for the discourse analysis-according to Van Dijk, Lakoff and Fairclough.

\begin{tabular}{|c|c|}
\hline 1. Topics & The topic represents what the discourse “is about” (Wodak/Meyer, 2001: 101). \\
\hline 2. Local meanings & $\begin{array}{l}\text { The local meanings are the kind of information that influences the mental models and } \\
\text { therefore the attitudes and opinions of recipients (Wodak/Meyer, 2001: 103). }\end{array}$ \\
\hline 3. Metaphors & $\begin{array}{l}\text { Metaphors contain modes of thought and thereby shape what we perceive as reality. } \\
\text { Different cultures understand metaphors in different ways (Lakoff/Johnson, 1980: 22). }\end{array}$ \\
\hline $\begin{array}{l}\text { 4. Subtle formal } \\
\text { structures }\end{array}$ & $\begin{array}{l}\text { The structures that are less controllable by speakers, as an example: intonation and pause } \\
\text { (Wodak/Meyer, 2001: 106). }\end{array}$ \\
\hline 5. Context models & $\begin{array}{l}\text { They guide us to understand what of the social situation is relevant for the participants of the speech. } \\
\text { It links texts with social situations (Wodak/Meyer, 2001: 108). }\end{array}$ \\
\hline 5.1 Intertextuality & $\begin{array}{l}\text { It is a matter of recontextualization-a movement from one context to another, } \\
\text { entailing particular transformations consequent upon how the material that is moved, } \\
\text { recontextualized, figures within that new context (Fairclough, 2003: 51). }\end{array}$ \\
\hline 5.2 Assumptions & $\begin{array}{l}\text { Types of implicitness as presuppositions, logical implications or entailments, } \\
\text { and implicatures (Fairclough, 2003: 40). }\end{array}$ \\
\hline 6. Event models & $\begin{array}{l}\text { Van Dijk affirms: "Language users not only form mental models of the situation they interact in, } \\
\text { but also of the events or situations they speak or write about" (Wodak/Meyer, 2001: 111). }\end{array}$ \\
\hline
\end{tabular}


Table 2. Social representations to understand a discourse.

1. Knowledge (personal, group, cultural)

2. Attitudes (attitudes as socially shared opinions)

3. Ideologies

He concludes further that discourse analysis "is thus at the same time cognitive, social and political analysis, but focuses rather on the role discourses play, both locally and globally, in society and its structure" (Wodak/Meyer, 2001: 118). The elements will be included in the analysis together with Cialdini's criteria on persuasive speech. It should be noted that to a big extent the criteria of Cialdini and CDA have touching points. For example, the relation of power and language can also be found in authority, one of Cialdini's criteria. Furthermore, Cialdini's social proof criteria can be found in shared opinions and attitudes. Social proof goes also together with the context of the speech — where it takes place and who the auditorium is as well as the historical context. According to these different items, the analysis will be undertaken in the following. It will be started with the context of the speech and afterwards the speech will be analyzed along the remaining criteria.

\section{Ronald Reagan's Evil Empire Speech}

\subsection{The Context of Reagan’s Speech}

The analysis of 'meanings' has to take into account the historical context, which for Reagan's speech will be outlined in short. Discourses have their own history. Chronological and sociocultural aspects produce meanings and social effects that cannot be reduced to the characteristics of the text alone. In this sense, Fowler notes that discourses are always socially situated, it occurs in a social environment and the construction of discourse "relates systematically and predictably to (these) contextual circumstances” (Richardson, 2007: 75).

Following this line of understanding, for the Critical Discourses Analysis (CDA) all discourses are historical and can only be understood with reference to their context. Moreover, CDA uses the concept of intertextuality (Wodak/Meyer, 2001: 15). As Fairclough explains: "Intertextuality is a matter of recontextualization-a movement from one context to another, entailing particular transformations consequent upon how the material that is moved, recontextualized, figures within that new context” (Fairclough, 2003: 51).

According to the National Centre for Public Policy Research (Anon.: n.d.), short before Reagan's "Evil Empire Speech" the American Congress was about to support a "nuclear freeze" policy—a bilateral nuclear disarmament policy of the US and the Soviet Union. It was born out of the idea of a disarmament researcher, Randall Forsberg, and resulted in a big "nuclear freeze" movement (Adams, 2002: 15). The Soviets supported this policy but President Reagan advised his administration against this policy and in favor of a "pro-defense" strategy. Shortly afterwards, on March 8, 1983, Ronald Reagan held his much known "Evil Empire Speech". It was directed to the National Association of Evangelicals in Orlando, Florida. The National Center for Public Policy Research further states that this speech was first written for President Reagan as a routine speech. Reagan himself added paragraphs that made this speech one of the most influencing and historical ones. I will dedicate one paragraph to his "Evil Empire Speech", which is his final point, but I will also describe how he leads to this point and make some general remarks on his whole speech. Thus the historical context is quite strong. The speech relates to the conflict between the USA and the Soviet Union during a time when nuclear armament was not seen as the single correct response. The location in which Reagan presents this speech is also a means that enforces his speech. He implicitly uses religious belief to support his speech. So he has even the church behind him, which should be an institution that represents peaceful coexistence.

The full length of Reagan's speech is around 29 minutes. It can be found in the internet (Address to the National Association of Evangelicals, 1983). The part I will analyze is the "Evil Empire" part, I mean the part where Reagan actually refers to the Soviets as an "evil empire" and where he talks about the "nuclear freeze" policy. A transcript of his speech is provided in annex 1; the "Evil Empire" part is in bold letters.

\subsection{Evaluation and Description of the Elements of Reagan's Speech}

\subsubsection{Reagan's Persuasiveness-General Characteristics Related to His Speech}

In my opinion the obvious purpose of Reagan's speech is to convince the auditorium about the righteousness of 
his nuclear policy, which he actually tackled in the final part of his speech. However, all of the other arguments leading to this final part had to be convincing as well. From my point of view Reagan was very persuasive in content and delivery of his speech for the whole length of his performance. In the following I will show why and how.

Analysts of critical discourses endorse what Habermas affirmed "language is also a medium of domination and social force. It serves to legitimize of organized power. In so far as the legitimations of power relations, [...] are not articulated, [...] language is also ideological” (Wodak/Meyer, 2001: 2). This can also be observed in Reagan's speech. His speech and the setting are directed to use social force to persuade his listeners.

For a man like Ronald Reagan I want to continue with his authority, as one of the principles of persuasion. Authority and power come together. I believe that he had lots of authority alone because of the fact that he was the President of the United States at that time and with that the leader of the Western World. Therefore, his formal authority cannot be questioned. In his speech he talked about political issues, especially about the opposition to the Soviet Union. Until the date of his speech, he had had a long career as a politician for example as Governor of California and he had been for around 2 years in office as president. All of that contributes to his credibility to talk about these issues as an expert and that gives him formal and informal authority.

Wodak explains that power does not come from language, but language can be used to challenge power. Power is signaled by grammatical forms within a text and also by a person's control of a social occasion by means of the genre of a text (Wodak/Meyer, 2001: 11). Reagan's power is already given through its position as the president of the US. From this position he is able to hold different speeches than other people are able to hold. He can always borrow from the power of this position and enforce his speeches. But not only the power through one's position is of importance in speeches.

In my opinion his informal authority is strong as well because he appears very self-confident and credible at the same time. This is supported by his deep and relaxed voice and his overall calm speech. He nearly never in his 29 minutes speech makes errors or uses words to fill gaps, whereas there was no need to because there were no unintended gaps. He was credible because he was nearly flawless in speech and seemed to know what he was talking about. One example for that is that he knew all the names of the people he cited or he talked about such as Jefferson, William Penn, the Senators Denton and Hatfield, C.S. Lewis etc. Furthermore, he talked about historical events, such as the civil war in the US, he cited the Bible by saying for example "Thou shalt love thy neighbor as thyself" and he referred to details of the work of his administration and the Congress.

Analyzing Reagan's discourse one can find some basic principles of a CDA. They are: 1) language is a social phenomenon; 2) not only individuals, but also institutions and social groupings have specific meanings and values that are expressed in language in systematic ways; 3) texts are the relevant units of language in communication; 4) readers/hearers are not passive recipients in their relationship to texts; 5) there are similarities between the language of science and the language of institutions, and so on (Wodak/Meyer, 2001: 6).

In the line number 175 of the transcript of Reagan's Evil Empire speech he turned to his last point, the nuclear freeze policy that he obviously refused. How he handled this part will be discussed in a later paragraph. At this point, I will outline the structure and content until his final part and how it contributed to his persuasiveness-above all authority and liking.

In terms of his liking he first broke the ice by making jokes but still remaining credible by staying calm and not being exaggerated. Then he tackled issues and conflicts of modern life and the church such as birth control, and he always took in the position of the church. To support his authority he used clear reasoning structures. One example is a reason-claim-example-structure from line 55 - 148, when he talked about the church that had done their job (reason) well because there is a religious awakening (claim) in the US. Additionally, he gave some statistics to underline this (example).

The more detailed structure and content are as follows: He first thanked for the invitation (lines 3 - 12). Then he delivered some jokes (lines 13 - 34). From lines 35 - 108 he pointed out the good things about religion and mentioned those who are against it. He gave examples on how politics had been dealing with birth control and religious speeches of students and at the same time he emphasized his being on the side of the church (lines 109 - 143). Reagan showed how his administration had been fighting for the same ideas as the church. He delivered the example that he had made clinics, prescribing birth control drugs to underage girls, notify it to the girls' parents. From line 144 - 149, Reagan appraised the audience for their achievements supported by statistics on how religiosity had improved in America, and he pointed out that this must continue. From line 149 - 166, there was a transition phase when he talked about America's errors in the past, such as the civil war, and that hate 
groups should be fought against. When he came to the critical issue-his last point-he already had the audience on his side. They were prepared and would digest the coming news easily.

I have already pointed out that his liking was supported by structure and content. Other facts contribute to his liking as well. It is an honor for the National Association of Evangelicals that the president holds a speech there and, with that, supports them strongly. It is a bit like a famous person used by a company for advertising to make its brand more known. In his speech Reagan tells the people what they like to hear und is humorous at the right times. It is a good example of intertextuality. Fairclough notes that "intertextuality is inevitable selective with respect to what is included and what is excluded from the events and texts represented" (Fairclough, 2003: 55). He uses 19 times the words God or Lord, he cites the Bible and he refers to connections between politics and religion. One example for that is his statement about the reference to God which is mentioned in the First Amendment of the US Constitution (lines 92 - 96). His big and authentic smile before he opened his speech and the warm words shortly afterwards also contributed to his liking. His making jokes were already mentioned. He made two jokes and all of them were related to politicians and clergymen. In the first one he showed that he believed in prayers and in the second he made fun of politicians in general by using the example that a rare case had happened and a politician came in heaven after his death, and since this is so seldom he got the best accommodation there. During the whole speech he addressed the whole audience with his eyes so that nobody had to feel neglected.

I think that liking and social proof are very strongly related. In his speech Reagan showed to be social proof by saying that he prayed and thus is a religious man. That is something he did in the very first part of his speech. There, he even mentioned his wife and was therefore implicitly referring to marriage (example of implicitness as presuppositions), which is a sacred institution.

At different points in his speech, Reagan created scarcity and hope. One very strong example for that was (lines 52 - 54) when he directly addressed the audience and said that religious people like the audience were the hope to survive and that liberty was the "last, best hope of men". In the following he talked about the opposition —about "radically different value systems" which "are not yet a majority" (lines 54 - 64).

He also used reciprocity, which increased his persuasiveness. I have already mentioned that Reagan said how he and his administration supported the same objectives as the church did. Two examples for that were the birth-control case, where he made the clinics notify the parents, and the public religious speeches of students, which he supported. Since he had done something for church it is now the church's turn to do something for him. At various points he makes appellations for support from the audience. An example is in the part immediately before the "Evil Empire Speech" (lines 160 - 166). There he asks the audience and the church in general for help against "hate groups". I believe that he introduced these strong words- "hate groups"-also with respect to the following part, when he would talk about the Soviets.

Some natural features supported his persuasiveness as well. They could fall under different categories such as social proof and liking. He wore a dark suit and dark tie, like most of the people sitting behind him. He was a lean man, not exceptionally tall or small and seemed to me to be in good shape. Additionally to what was mentioned about his voice, it was very clear and understandable. He modulated the melody, but never exaggerated it.

I want to mention some facts about his speech that leave room for interpretation whether it was positive or negative in terms of an effective speech and persuasiveness. He never modulated the volume of his voice very much. The average length of his sentences was 21.6 words per sentence. His hand movements were very thriftily.

My final remark is dedicated to the still not mentioned principle of persuasion-commitment and consistency. It is hard to get a "yes" from the audience since the speech is not thought to be so much interactive. But I believe he got it anyway. He got it in the form of applause and people standing up to support their agreement. In the course of his speech he received a lot and very intense applauses.

\subsubsection{Reagan's Persuasiveness-The "Evil Empire" Part}

I will now turn to the last part of Reagan's speech. In the transcript in annex 1 it is written in bold. I will not touch upon the final part, which comes after the "Evil Empire" part.

The structure and content of this part contributed to his authority the same way as they had done before-by having included precise examples and matters that are important to the church. Additionally, Reagan increased his credibility by always explaining how that what he proposes was in line with the belief of the church.

In the first part for example, he pointed out the opposition of the communists against the church—again by 
using specific names and dates. Afterwards, Reagan talked about that he did everything he could to prevent nuclear armament—and again, he does this specifically. He mentioned the example of his proposal of cutting strategic ballistic missiles by 50\%. But then he turned to talk about higher values, freedom and the belief in God (lines 175 - 185), that would justify his pro-defense attitude. In the following he talked about the "nuclear freeze" policy and how dangerous it would be at this point in time. "I would agree to a freeze, if only we could freeze the Soviets' global desires” underlines his point of view by cleverly playing with words (line 188). He lays down why a policy of strength is better to achieve the objectives of the US.

He again uses scarcity to persuade the people from his armament plans by talking about "aging forces" (line 194). With that Reagan proposes to modernize capabilities to defend the US.

One very strong example contributes to several principles of persuasiveness, namely authority, liking and social proof. At lines 204 - 205 Reagan started talking: He once was present during a speech of a young man who said he would rather see his loved girls "die now, still believing in God, than have them grow up under communism and one day die no longer believing in God". This is an extreme example that puts the belief in God on the top of all values. Reagan strongly agrees to this man and praises him implicitly for his remark. With that he emphasizes first his own strong faith in God and second, that extreme measures are justified to protect faith.

He furthered is persuasiveness through showing another Christian quality: sympathy. He said that one should pray for those "who live in that totalitarian darkness". But afterwards Reagan clearly turned back to his line by stating that until the totalitarian regime is in place it remains to be the "focus of evil".

To build credibility for the righteousness of his plans and commitment to follow him he used a very long quotation by C.S. Lewis. According to that quotation passiveness is "the greatest evil" leading to its final result such as "concentration and labor camps". This is followed by an appellation not to be passive but to support America to become strong again. In this part he also refers to the Soviet Union as an "evil empire", that is an example of metaphor. It is observed that Reagan uses metaphors quite often and this is his strongest one. Metaphors contain modes of thought and thereby shape what we perceive as reality. Different cultures understand metaphors in a different way (Lakoff/Johnson, 1980: 22).

\section{Summary and Conclusion}

Ronald Reagan's Evil Empire Speech, which he held in 1983 at the National Association of Evangelicals, was aimed at weakening the upcoming opinion that nuclear armament was not the right answer to the Russian nuclear policy. The total length of his speech was about half an hour, whereas the final part was dedicated to Reagan's political concerns, and the prior part can clearly be seen as a part that prepares the audience for that what was coming and made them digest it as well as it was possible.

To conclude my findings about President Reagan's “Evil Empire Speech”, I come to an exceptionally positive result with regard to his persuasiveness. He strongly contributed to all of the principles of persuasiveness such as reciprocity, authority, commitment, liking, scarcity and social proof. He did it through his voice, a flawless speech, showing similarities with the church, his own faithfulness, the presentation of strong examples and a good balance between humor and seriousness. Additionally, he used strong metaphors especially the notion "evil empire", that stuck to the peoples' minds and had an impact on them. He also implicitly distinguishes the evil from the ones who are not evil—the US. Thus, he makes the American people feel better, to ensure that they do the right thing when following him. He also emphasizes his relation to Christianity and even more he placed religious people above him when he made a joke about clergy men and politicians. And in addition to his authority as the president of the US, he borrowed the authority of various respected men through citing them. Thus, he did not only use his power or the power of his position but also the power of other men, which were accepted for the philosophical wisdom.

\section{References}

Cialdini, R. B. (2007). Influence: The Psychology of Persuasion. New York: Harper Collins.

(1983). "Evil Empire” Speech by President Reagan—Address to the National Association of Evangelicals. http://www.youtube.com/watch?v=FcSm-KAEFFA

National Centre for Public Policy Research (2011). Evil Empire Speech. http://www.nationalcenter.org/ReaganEvilEmpire1983.html

Fairclough, N. (2003). Analysing Discourse. London: Routledge. 
Lakoff, G., \& Johnson, M. (1980). Metaphors We Live by. Chicago: University of Chicago Press.

Neves, M. (1997). A Gramática Funcional. Sao Paulo: Martins Fontes.

Richardson, J. E. (2007). Analysing Newspapers. Houndmills: Palgrave Macmillan.

Adams, D. (2002). The American Peace Movements. http://www.culture-of-peace.info/apm/title-page.html

Vieira, A. (1993). Sermoes (Obras Completas do Padre Antonio Vieira) (Vol. 1). Porto: Artes Gráficas.

Wodak, R., \& Meyer, M. (2001). Methods of Critical Discourse Analysis. London: Sage Publications. 


\section{Annex 1}

\section{Transcript of Reagan's Evil Empire Speech}

www.nationalcenter.org

Reverend clergy all, Senator Hawkins, distinguished members of the Florida congressional delegation, and all of you:

I can't tell you how you have warmed my heart with your welcome. I'm delighted to be here today.

Those of you in the National Association of Evangelicals are known for your spiritual and humanitarian work. And I would be especially remiss if I didn't discharge right now one personal debt of gratitude. Thank you for your prayers. Nancy and I have felt their presence many times in many ways. And believe me, for us they've made all the difference.

The other day in the East Room of the White House at a meeting there, someone asked me whether I was aware of all the people out there who were praying for the President. And I had to say, "Yes, I am. I've felt it. I believe in intercessionary prayer."

But I couldn't help but say to that questioner after he'd asked the question that —or at least say to them that if sometimes when he was praying he got a busy signal, it was just me in there ahead of him.

[Laughter]

I think I understand how Abraham Lincoln felt when he said, "I have been driven many times to my knees by the overwhelming conviction that I had nowhere else to go.”

From the joy and the good feeling of this conference, I go to a political reception.

[Laughter]

Now, I don't know why, but that bit of scheduling reminds me of a story—[laughter]—which I'll share with you.

An evangelical minister and a politician arrived at Heaven's gate one day together. And St. Peter, after doing all the necessary formalities, took them in hand to show them where their quarters would be. And he took them to a small, single room with a bed, a chair, and a table and said this was for the clergyman. And the politician was a little worried about what might be in store for him. And he couldn't believe it then when St. Peter stopped in front of a beautiful mansion with lovely grounds, many servants, and told him that these would be his quarters.

And he couldn't help but ask, he said, “But wait, how-here's something wrong-how do I get this mansion while that good and holy man only gets a single room?" And St. Peter said, "You have to understand how things are up here. We've got thousands and thousands of clergy. You're the first politician who ever made it.”

[Laughter]

But I don't want to contribute to a stereotype.

[Laughter]

So, I tell you there are a great many God-fearing, dedicated, noble men and women in public life, present company included. And yes, we need your help to keep us ever mindful of the ideas and the principles that brought us into the public arena in the first place. The basis of those ideals and principles is a commitment to freedom and personal liberty that, itself, is grounded in the much deeper realization that freedom prospers only where the blessings of God are avidly sought and humbly accepted.

The American experiment in democracy rests on this insight. Its discovery was the great triumph of our Founding Fathers, voiced by William Penn when he said, "If we will not be governed by God, we must be governed by tyrants."

Explaining the inalienable rights of men, Jefferson said, "The God who gave us life, gave us liberty at the same time.”

And it was George Washington who said that "of all the dispositions and habits which lead to political prosperity, religion and morality are indispensable supports.”

And finally, that shrewdest of all observers of American democracy, Alexis de Tocqueville, put it eloquently after he had gone on a search for the secret of America's greatness and genius - and he said, "Not until I went into the churches of America and heard her pulpits aflame with righteousness did I understand the greatness and the genius of America. America is good. And if America ever ceases to be good, America will cease to be great.”

Well, I'm pleased to be here today with you who are keeping America great by keeping her good. Only through your work and prayers and those of millions of others can we hope to survive this perilous century and keep alive this experiment in liberty - this last, best hope of man. 
I want you to know that this administration is motivated by a political philosophy that sees the greatness of America in you, her people, and in your families, churches, neighborhoods, communities-the institutions that foster and nourish values like concern for others and respect for the rule of law under God.

Now, I don't have to tell you that this puts us in opposition to, or at least out of step with, a prevailing attitude of many who have turned to a modern-day secularism, discarding the tried and time-tested values upon which our very civilization is based. No matter how well intentioned, their value system is radically different from that of most Americans. And while they proclaim that they're freeing us from superstitions of the past, they've taken upon themselves the job of superintending us by government rule and regulation. Sometimes their voices are louder than ours, but they are not yet a majority.

An example of that vocal superiority is evident in a controversy now going on in Washington. And since I'm involved, I've been waiting to hear from the parents of young America. How far are they willing to go in giving to government their prerogatives as parents?

Let me state the case as briefly and simply as I can. An organization of citizens, sincerely motivated and deeply concerned about the increase in illegitimate births and abortions involving girls well below the age of consent, sometime ago established a nationwide network of clinics to offer help to these girls and, hopefully, alleviate this situation. Now, again, let me say, I do not fault their intent. However, in their well-intentioned effort, these clinics have decided to provide advice and birth control drugs and devices to underage girls without the knowledge of their parents.

For some years now, the federal government has helped with funds to subsidize these clinics. In providing for this, the Congress decreed that every effort would be made to maximize parental participation. Nevertheless, the drugs and devices are prescribed without getting parental consent or giving notification after they've done so. Girls termed "sexually active" - and that has replaced the word "promiscuous"-are given this help in order to prevent illegitimate birth or abortion.

Well, we have ordered clinics receiving federal funds to notify the parents such help has been given. One of the nation's leading newspapers has created the term "squeal rule" in editorializing against us for doing this, and we're being criticized for violating the privacy of young people. A judge has recently granted an injunction against an enforcement of our rule. I've watched TV panel shows discuss this issue, seen columnists pontificating on our error, but no one seems to mention morality as playing a part in the subject of sex.

Is all of Judeo-Christian tradition wrong? Are we to believe that something so sacred can be looked upon as a purely physical thing with no potential for emotional and psychological harm? And isn't it the parents' right to give counsel and advice to keep their children from making mistakes that may affect their entire lives?

Many of us in government would like to know what parents think about this intrusion in their family by government. We're going to fight in the courts. The right of parents and the rights of family take precedence over those of Washington-based bureaucrats and social engineers.

But the fight against parental notification is really only one example of many attempts to water down traditional values and even abrogate the original terms of American democracy. Freedom prospers when religion is vibrant and the rule of law under God is acknowledged. When our Founding Fathers passed the First Amendment, they sought to protect churches from government interference. They never intended to construct a wall of hostility between government and the concept of religious belief itself.

The evidence of this permeates our history and our government. The Declaration of Independence mentions the Supreme Being no less than four times. "In God We Trust" is engraved on our coinage. The Supreme Court opens its proceedings with a religious invocation. And the members of Congress open their sessions with a prayer. I just happen to believe the schoolchildren of the United States are entitled to the same privileges as Supreme Court Justices and Congressmen.

Last year, I sent the Congress a constitutional amendment to restore prayer to public schools. Already this session, there's growing bipartisan support for the amendment, and I am calling on the Congress to act speedily to pass it and to let our children pray.

Perhaps some of you read recently about the Lubbock school case, where a judge actually ruled that it was unconstitutional for a school district to give equal treatment to religious and nonreligious student groups, even when the group meetings were being held during the students' own time. The First Amendment never intended to require government to discriminate against religious speech.

Senators Denton and Hatfield have proposed legislation in the Congress on the whole question of prohibiting discrimination against religious forms of student speech. Such legislation could go far to restore freedom of reli- 
gious speech for public school students. And I hope the Congress considers these bills quickly. And with your help, I think it's possible we could also get the constitutional amendment through the Congress this year.

More than a decade ago, a Supreme Court decision literally wiped off the books of 50 States statutes protecting the rights of unborn children. Abortion on demand now takes the lives of up to one and a half million unborn children a year. Human life legislation ending this tragedy will some day pass the Congress, and you and I must never rest until it does. Unless and until it can be proven that the unborn child is not a living entity, then its right to life, liberty, and the pursuit of happiness must be protected.

You may remember that when abortion on demand began, many, and, indeed, I'm sure many of you, warned that the practice would lead to a decline in respect for human life, that the philosophical premises used to justify abortion on demand would ultimately be used to justify other attacks on the sacredness of human life-infanticide or mercy killing. Tragically enough, those warnings proved all too true. Only last year a court permitted the death by starvation of a handicapped infant.

I have directed the Health and Human Services Department to make clear to every health care facility in the United States that the Rehabilitation Act of 1973 protects all handicapped persons against discrimination based on handicaps, including infants. And we have taken the further step of requiring that each and every recipient of Federal funds who provides health care services to infants must post and keep posted in a conspicuous place a notice stating that "discriminatory failure to feed and care for handicapped infants in this facility is prohibited by Federal law." It also lists a 24-hour, toll-free number so that nurses and others may report violations in time to save the infant's life.

In addition, recent legislation introduced in the Congress by Representative Henry Hyde of Illinois not only increases restrictions on publicly financed abortions, it also addresses this whole problem of infanticide. I urge the Congress to begin hearings and to adopt legislation that will protect the right of life to all children, including the disabled or handicapped.

Now, I'm sure that you must get discouraged at times, but you've done better than you know, perhaps. There's a great spiritual awakening in America, a renewal of the traditional values that have been the bedrock of America's goodness and greatness.

One recent survey by a Washington-based research council concluded that Americans were far more religious than the people of other nations; 95 percent of those surveyed expressed a belief in God and a huge majority believed the Ten Commandments had real meaning in their lives. And another study has found that an overwhelming majority of Americans disapprove of adultery, teenage sex, pornography, abortion, and hard drugs. And this same study showed a deep reverence for the importance of family ties and religious belief.

I think the items that we've discussed here today must be a key part of the Nation's political agenda. For the first time the Congress is openly and seriously debating and dealing with the prayer and abortion issues—and that's enormous progress right there. I repeat: America is in the midst of a spiritual awakening and a moral renewal. And with your Biblical keynote, I say today, "Yes, let justice roll on like a river, righteousness like a never-failing stream."

"Now, obviously, much of this new political and social consensus I've talked about is based on a positive view of American history, one that takes pride in our country's accomplishments and record. But we must never forget that no government schemes are going to perfect man. We know that living in this world means dealing with what philosophers would call the phenomenology of evil or, as theologians would put it, the doctrine of sin.

There is sin and evil in the world, and we're enjoined by Scripture and the Lord Jesus to oppose it with all our might. Our nation, too, has a legacy of evil with which it must deal. The glory of this land has been its capacity for transcending the moral evils of our past. For example, the long struggle of minority citizens for equal rights, once a source of disunity and civil war, is now a point of pride for all Americans. We must never go back. There is no room for racism, anti-Semitism, or other forms of ethnic and racial hatred in this country.

I know that you've been horrified, as have I, by the resurgence of some hate groups preaching bigotry and prejudice. Use the mighty voice of your pulpits and the powerful standing of your churches to denounce and isolate these hate groups in our midst. The commandment given us is clear and simple: "Thou shalt love thy neighbor as thyself.” But whatever sad episodes exist in our past, any objective observer must hold a positive view of American history, a history that has been the story of hopes fulfilled and dreams made into reality. Especially in this century, America has kept alight the torch of freedom, but not just for ourselves but for millions of others around the world.

And this brings me to my final point today. During my first press conference as President, in answer to a 
direct question, I pointed out that, as good Marxist-Leninists, the Soviet leaders have openly and publicly declared that the only morality they recognize is that which will further their cause, which is world revolution. I think I should point out I was only quoting Lenin, their guiding spirit, who said in 1920 that they repudiate all morality that proceeds from supernatural ideas - that's their name for religion-or ideas that are outside class conceptions. Morality is entirely subordinate to the interests of class war. And everything is moral that is necessary for the annihilation of the old, exploiting social order and for uniting the proletariat.

Well, I think the refusal of many influential people to accept this elementary fact of Soviet doctrine illustrates an historical reluctance to see totalitarian powers for what they are. We saw this phenomenon in the 1930's. We see it too often today. This doesn't mean we should isolate ourselves and refuse to seek an understanding with them. I intend to do everything I can to persuade them of our peaceful intent, to remind them that it was the West that refused to use its nuclear monopoly in the forties and fifties for territorial gain and which now proposes 50-percent cut in strategic ballistic missiles and the elimination of an entire class of land-based, intermediate-range nuclear missiles.

At the same time, however, they must be made to understand we will never compromise our principles and standards. We will never give away our freedom. We will never abandon our belief in God. And we will never stop searching for a genuine peace. But we can assure none of these things America stands for through the so-called nuclear freeze solutions proposed by some.

The truth is that a freeze now would be a very dangerous fraud, for that is merely the illusion of peace. The reality is that we must find peace through strength.

I would agree to a freeze if only we could freeze the Soviets' global desires. A freeze at current levels of weapons would remove any incentive for the Soviets to negotiate seriously in Geneva and virtually end our chances to achieve the major arms reductions which we have proposed. Instead, they would achieve their objectives through the freeze.

A freeze would reward the Soviet Union for its enormous and unparalleled military buildup. It would prevent the essential and long overdue modernization of United States and allied defenses and would leave our aging forces increasingly vulnerable. And an honest freeze would require extensive prior negotiations on the systems and numbers to be limited and on the measures to ensure effective verification and compliance. And the kind of a freeze that has been suggested would be virtually impossible to verify. Such a major effort would divert us completely from our current negotiations on achieving substantial reductions.

A number of years ago, I heard a young father, a very prominent young man in the entertainment world, addressing a tremendous gathering in California. It was during the time of the Cold War, and communism and our own way of life were very much on people's minds. And he was speaking to that subject. And suddenly, though, I heard him saying, "I love my little girls more than anything"-And I said to myself, “Oh, no, don't. You can't-don't say that."

But I had underestimated him. He went on: "I would rather see my little girls die now, still believing in God, than have them grow up under communism and one day die no longer believing in God.”

There were thousands of young people in that audience. They came to their feet with shouts of joy. They had instantly recognized the profound truth in what he had said, with regard to the physical and the soul and what was truly important.

Yes, let us pray for the salvation of all of those who live in that totalitarian darkness--pray they will discover the joy of knowing God. But until they do, let us be aware that while they preach the supremacy of the state, declare its omnipotence over individual man, and predict its eventual domination of all peoples on the Earth, they are the focus of evilin the modern world.

It was C.S. Lewis who, in his unforgettable "Screwtape Letters," wrote: "The greatest evil is not done now in those sordid 'dens of crime' that Dickens loved to paint. It is not even done in concentration camps and labor camps. In those we see its final result. But it is conceived and ordered (moved, seconded, carried and minuted) in clear, carpeted, warmed, and well-lighted offices, by quiet men with white collars and cut fingernails and smooth-shaven cheeks who do not need to raise their voice."

Well, because these "quiet men" do not "raise their voices"; because they sometimes speak in soothing tones of brotherhood and peace; because, like other dictators before them, they're always making "their final territorial demand," some would have us accept them at their word and accommodate ourselves to their aggressive impulses. But if history teaches anything, it teaches that simple-minded appeasement or 
wishful thinking about our adversaries is folly. It means the betrayal of our past, the squandering of our freedom.

So, I urge you to speak out against those who would place the United States in a position of military and moral inferiority. You know, I've always believed that old Screwtape reserved his best efforts for those of you in the church. So, in your discussions of the nuclear freeze proposals, I urge you to beware the temptation of pride - the temptation of blithely declaring yourselves above it all and label both sides equally at fault, to ignore the facts of history and the aggressive impulses of an evil empire, to simply call the arms race a giant misunderstanding and thereby remove yourself from the struggle between right and wrong and good and evil.

I ask you to resist the attempts of those who would have you withhold your support for our efforts, this administration's efforts, to keep America strong and free, while we negotiate real and verifiable reductions in the world's nuclear arsenals and one day, with God's help, their total elimination.

While America's military strength is important, let me add here that I've always maintained that the struggle now going on for the world will never be decided by bombs or rockets, by armies or military might. The real crisis we face today is a spiritual one; at root, it is a test of moral will and faith.

Whittaker Chambers, the man whose own religious conversion made him a witness to one of the terrible traumas of our time, the Hiss-Chambers case, wrote that the crisis of the Western World exists to the degree in which the West is indifferent to God, the degree to which it collaborates in communism's attempt to make man stand alone without God. And then he said, for Marxism-Leninism is actually the second oldest faith, first proclaimed in the Garden of Eden with the words of temptation, "Ye shall be as gods."

The Western world can answer this challenge, he wrote, "but only provided that its faith in God and the freedom He enjoins is as great as communism's faith in Man."

I believe we shall rise to the challenge. I believe that communism is another sad, bizarre chapter in human history whose last pages even now are being written. I believe this because the source of our strength in the quest for human freedom is not material, but spiritual. And because it knows no limitation, it must terrify and ultimately triumph over those who would enslave their fellow man. For in the words of Isaiah: "He give the power to the faint; and to them that have no might He increased strength But they that wait upon the Lord shall renew their strength; they shall mount up with wings as eagles; they shall run, and not be weary."

Yes, change your world. One of our Founding Fathers, Thomas Paine, said, "We have it within our power to begin the world over again." We can do it, doing together what no one church could do by itself.

God bless you, and thank you very much. 